\title{
POWER MARKET COUPLING: TOWARDS HARMONISED ELECTRICITY POLICIES IN THE EAST AFRICAN COMMUNITY
}

\begin{abstract}
The ambitious plans of the East African Community (EAC) to provide adequate electricity in the region have continued to generate substantial interest among experts in academia, industry and government. The communal efforts to realise such targets are predicated on individual capacities and cooperative endeavour. This article focuses on a legal assessment of the EAC energy market coupling with a special emphasis on examining whether a harmonised approach is possible from two perspectives. First, practical industry concerns and, second, the legal framework within which those concerns should be addressed. This article argues that there is strong potential for a harmonised approach supported with legal convergence. One important index of success in this area would be the promotion and protection of foreign investment to ensure enough electricity supply.
\end{abstract}

\section{Introduction}

Several projects have been either planned or are ongoing - both sets are aimed at attaining electricity markets coupling ${ }^{1}$ in the East African Community (EAC). ${ }^{2}$ One such project is the Nile Equatorial Lakes Countries Project (NELSAP) which concerns the construction of $769 \mathrm{~km}$ of $110 \mathrm{kv}$ and $220 \mathrm{kv}$ lines as well as reinforcement of 17 transformer stations. ${ }^{3}$ These transmission lines include the Uganda-Rwanda interconnection, the Kenya-Uganda interconnection and the upgrading of the Burundi, DR Congo, and Rwanda interconnections. These projects are key to boosting the EAC power markets and this study assesses the legal and regulatory frameworks that underpin the integration of these electricity markets. ${ }^{4}$ Under

\footnotetext{
*Geoffrey A Mabea, PhD, Centre for Energy, Petroleum and Mineral Law and Policy at the University of Dundee, Scotland. Email: g.mabea@dundee.ac.uk; Pontian N Okoli, PhD, School of Law at the University of Stirling, Scotland. Email: pontian.okoli@stir.ac.uk

${ }^{1}$ Essentially, this links the various countries with a robust transmission infrastructure to enhance electricity trade among the EAC electricity markets.

2 The EAC comprises Kenya, Uganda, Tanzania, Rwanda, Burundi and South Sudan.

3 <http://nelsap.nilebasin.org/index.php/en/power/power-trade-and-development> accessed 7 May 2019

${ }_{4}^{4}$ Tractebel, The Project for the Interconnection of Electric Grids of the Nile Equatorial Lakes Countries (NELSAP Report 2017).
} 
these projects, the Kenya-Tanzania interconnection will be upgraded to a $400 \mathrm{KV}$ transmission line and several interconnections in the country transmission networks will be upgraded as well. The interconnection upgrade is implemented by various national utilities in the relevant countries. These include the Energy Water and Sanitation Authority (EWSA), Uganda Electricity Transmission Company Limited (UETCL), Régie de distribution d'eau (REGIDESO), Kenya Electricity Transmission Company (KETRACO) and Tanzania Electric Supply Company Limited (TANESCO) as well as Société nationale d'électricité (SNEL) for DR Congo. 5

Some considerations are critical to attaining robust electricity markets in the region. These considerations include: electricity market design, technical standards, Transmission System Operator (TSO) regulations, accommodating bulk renewable energy sources, and harmonisation of policies on electricity trade in the region. Transitioning to near $100 \%$ Renewables (RES) integration should be pursued incrementally in a strategic manner over a period. Such strategy should also be predicated on relevant legal, policy and institutional changes since the transformation required can be rather complex. ${ }^{6}$ There are, however, several impediments to attaining such changes. An analysis of the electricity policies of EAC Partner States reveals the need to ensure privatisation, increase competition and electricity market liberalisation. ${ }^{7}$ The different capacities of Partner States should be carefully assessed in the context of electricity market operators. The efforts of various EAC Partner States to promote domestic legal and institutional reforms are helpful, but there is a need to consider reforms in a manner that ensures overarching regional progress to ensure efficient and sufficient electricity supply. Such regional perspective requires a synergy between legal and institutional frameworks among Partner States. ${ }^{8}$ Achieving efficient electricity supply is not only dependent on domestic cooperation, but also ensuring such cooperation is not undermined by different domestic attitudes in any relevant context. Thus, this article partly argues that the security of reliable electricity supply is predicated on securing: investments, institutions with cross-border implications and cyber support. This is especially because electricity market liberalisation in

\footnotetext{
5 ibid.

${ }^{6}$ G Papaefthymiou and K Dragoon. 'Towards 100\% Renewable Systems: Uncapping Power System Flexibility' (2016) 92 Energy Policy 69.

${ }^{7}$ See discussions in sections 2 and 3 of this article.

${ }^{8}$ In this context, cooperation between governments and private investors is complementary. For the argument that this cooperation is necessary to stimulate investment, see A Aly et al, 'Barriers to Large-scale Solar Power in Tanzania' (2019) 48 Energy for Sustainable Development 43, 45.
} 
the EAC region increases the prospect of foreign investors dealing with the EAC. ${ }^{9}$ In going beyond existing literature, this article examines such issues in an interconnected manner and explores the use of a justice system that can support the efforts of the EAC to attain legal, policy and institutional goals in a harmonised manner.

To realise effective electricity markets coupling, it is necessary to review existing laws and regulations as well as the establishment of relevant regional and internal institutions that would make it possible to implement a robust coupled electricity market. Members of the EAC are at different levels of restructuring, but relevant roadmaps are generally similar and all the countries are developing. This is partly why the EAC has emerged as an important platform for the countries in the region to adopt progressive strategies through a unified policy framework.

The implementation of the regional projects geared towards the development of a regional market requires some level of legal convergence for market operations and harmonisation of key market rules. The EAC legal framework will first provide a useful context to understand how the countries involved stand considering the electricity markets generally. This is the basis on which the comparative analysis in this article will be conducted with a view to examining individual EAC members' approaches and how such approaches to key laws and energy policies can be harmonised.

\section{Bases for Comparative Analysis in the EAC}

About half of the people worldwide who lack access to electricity live in sub-Saharan Africa and East Africa is particularly affected. ${ }^{10}$ Even those who have access to electricity often find that supply can be epileptic or insufficient. ${ }^{11}$ Most of the EAC countries are currently among the fastest growing African economies. One of the implications of this development is the need for an electricity market that can support economic expansion and sustainable development. International energy cooperation and coordination can pose their own challenges especially

\footnotetext{
${ }^{9}$ This involves a focus on the 'EAC as a region, in spite of visible differences among the member countries'. See S Penev and A Marušić, 'Attractiveness of East African Community (EAC) for Foreign Direct Investment' (2014) 27(3-4) Economic Analysis 35.

10 <https://www.marsdd.com/news/east-africa-solar-power-innovations/> accessed 11 April 2019.

${ }^{11}$ In such countries, some companies lose as much as $31 \%$ in sales <https://www.cgdev.org/article/new-studysub-saharan-african-countries-unreliable-power-outages-cost-companies-much-31> accessed 7 May 2009> See also V Ramachandran, MK Shah and T Moss, 'How Do African Firms Respond to Unreliable Power?' (Working Paper 493 - Center for Global Development, 2008) < https://www.cgdev.org/publication/how-doafrican-firms-respond-unreliable-power-exploring-firm-heterogeneity-using-k-means> accessed 7 May 2009.
} 
where there are somewhat divergent interests (for example, one country may focus on security while another is more concerned about the environment). ${ }^{12}$ However, a specific articulation of how a region can attain a common energy objective is foundational in efforts to attain a harmonised approach with respect to challenges that relevant countries tackle. In the EAC, there is a clear overarching policy that serves as a common denominator for comparative analysis.

Kenya, Tanzania and Uganda already had a history of international cooperation under several regional endeavours as long ago as the first half of the 20th century. ${ }^{13}$ This cooperation expanded officially when Rwanda and Burundi became full members of the EAC in 2007 after acceding to the EAC Treaty. ${ }^{14}$ South Sudan is the most recent member of the EAC having joined in 2016, nearly a decade after Rwanda and Burundi joined. ${ }^{15}$ South Sudan is excluded from the scope of this article partly because it has yet to develop a robust internal policy and institutional framework as it gained independence only half a decade prior to becoming a member of the EAC. ${ }^{16}$ South Sudan will nonetheless look to consolidate the benefits of becoming a member of the EAC, especially as it had already explored possible access to cheaper diesel (for self-generated electricity which is practically how the country has been run) through Kenyan and Ugandan road networks. ${ }^{17}$ There is thus a common thread of energy interests with a special focus on electricity needs for the countries involved and in the context of this article. Furthermore, an ambitious Electricity Master Plan was developed as a blue print for 'generation and transmission expansion in the region for the next 25 years'. ${ }^{18}$ Such strategies are anchored to the EAC Treaty. ${ }^{19}$ Under the Treaty, Partner States (used interchangeably with 'member countries' in this article') are required to 'adopt policies and

\footnotetext{
${ }^{12}$ A Hermanson, 'Energy Security in a Multi-level Governance Perspective' (2018) 98 Marine Policy 301.

13 <https://www.eac.int/eac-history> accessed 11 April 2019.

$14<$ https://www.eac.int/health/index.php?option=com_content\&view=article\&id=57\&Itemid=110 $>$ accessed 14 April 2019

${ }^{15}$ E Pichon, 'Economic Partnership Agreement with the East African Community', European Parliament Research Service $2018<$ http://www.europarl.europa.eu/RegData/etudes/BRIE/2018/620218/EPRS_BRI(2018)620218_EN.pdf> accessed 7 May 2018.

${ }^{16}$ The civil war that started shortly after independence did not help and South Sudan has the worst access to electricity in the world. See D Mosersky and DM Kammen, 'South Sudan's Renewable Energy Potential: A Building Block for Peace' (2018) United States Institute for Peace (Report).

$<$ https://www.usip.org/sites/default/files/2018-01/sr418-south-sudans-renewable-energy-potential-a-buildingblock-for-peace.pdf $>$ accessed 11 April 2019.

17 ibid. See also <https://www.eac.int/press-releases/1359-eac-secretariat-conducts-a-one-day-sensitizationmission-to-the-republic-of-south-sudan> accessed 11 April 2019.

$18<$ https://www.eac.int/statements/566-986-699-address-by-secretary-general-amb-liberat-mfumukeko-duringthe-press-conference-on-10th-october-2016-at-the-eac-headquarters $>$ accessed 7 May 2019.

19 Treaty for the Establishment of the East Africa Community (signed on 30 November 1999 as amended in 2006 and 2007) art 101.
} 
mechanisms to promote the efficient exploitation, development, joint research and utilisation of various energy resources available within the region'. ${ }^{20}$ The Treaty also provides for the development of an integrated policy on rural electrification ${ }^{21}$ and inter-Partner State electrical grid interconnections. ${ }^{22}$ The overarching Treaty provisions and aims support a comparative methodology that is appropriate for ascertaining the common core with respect to applicable legal frameworks and policies.

This article is based on comparative legal research. ${ }^{23}$ This approach involves a consideration of differences that exist between the comparators, ${ }^{24}$ partly because this also helps to explore why relevant indicators exist. ${ }^{25}$ The differences between countries are factored in under relevant Treaty provisions which makes the Treaty a robust framework with which sustainable progress can take place. For example, the principle of variable geometry is important in the integration of the EAC. This principle connotes cooperation among groups and integration of different schemes or fields may occur at different speeds. ${ }^{26}$ Thus, peculiar challenges of individual Partner States do not undermine the common parameters that are relevant to determine the unifying factors between the Partner States with a view to attaining the ultimate end of providing adequate and efficient electricity market in the region. The East African Court of Justice has interpreted this operational principle of variable geometry in a progressive manner that ensures no time is lost even though some individual Partner States may be unable to progress at the same speed as others. ${ }^{27}$

This article investigates the legal rules, the structures to assess the significance of their similarities and differences. A comparative analysis of the legal rules and structure enables the underlying objectives necessary regulatory interventions to be realised. ${ }^{28}$ The research draws upon a wide range of sources, including the primary electricity legislation in Kenya, Uganda,

\footnotetext{
20 ibid art 101(1).

21 ibid art $101(2)(\mathrm{c})$.

22 ibid art 101(2)(d).

${ }^{23}$ HP Glenn, 'Comparing' in E Orucu and D Nelken (eds) Comparative Law: A Handbook (Oxford and Portland 2007) 92.

${ }^{24}$ RB Schlesinger, 'The Past and the Future of Comparative Law' (1995) 43 American Journal of Comparative Law 477.

${ }^{25} \mathrm{~J}$ Husa, A New Introduction to Comparative Law (Hart Publishing 2015) ch 7.

${ }^{26}$ Art 7(1)(e) of the Treaty.

${ }^{27}$ In the Advisory Opinion to the Council of Ministers Application No 1 of 2008; Advisory Opinion No 1 of 2010. This is an operational principle that Partner States such as South Sudan will find beneficial and supportive.

28 J Bell, 'Legal Research and the Distinctiveness of Comparative Law' in MV Hoecke (ed) Methodologies of Legal Research: Which Kind of Method for What Kind of Discipline? (Hart Publishing 2011) 155-176.
} 
Tanzania, Rwanda, and Burundi. Secondary sources include academic literature, energy policies and reports on the Northern Corridor Integration projects as well as electricity power masterplans for each jurisdiction.

Considering the prospects for the coupling of the EAC market, this article first evaluates how the existing electricity laws compare if the regional market is to integrate. The electricity laws and policies of each Partner State is examined vis-à-vis the operational principle of variable geometry. This principle is of importance in this article because it means that institutional inadequacies in any Partner State need not frustrate holistic progress towards attaining common ends and that a harmonised approach is possible within defined parameters. The electricity policies of the Partner States provide the context within which relevant institutional and legal frameworks can be interpreted and assessed.

\section{Electricity Policies of Individual Partner States}

An overview of the EAC roadmap in regional electrification has been provided. There is a need to provide further specific context with respect to practical challenges, liberalisation of the electricity market, and domestic institutions that support electricity market coupling. This section provides a summary of each Partner State's position and unpacks the challenges which Partner States should address to be in strategic positions to benefit from regional harmonisation efforts. It is necessary first to consider privatisation because many leading scholars have found that privatisation may lead to increased efficiency. ${ }^{29}$

\subsection{Privatisation and Electricity Market Liberalisation}

Inadequate access to affordable and reliable electricity has impeded the attainment of socioeconomic goals in the East African region. Less than half of the population have access to electricity in Tanzania. ${ }^{30}$ Only about $10 \%$ of the Burundian population have access to

\footnotetext{
${ }^{29}$ P Michael, 'Evaluating the Evidence on Electricity Reform: Lessons for the South East Europe (SEE) Market' (2009) 17 Utilities Policy 13-23. See also S Estrin and A Pelletier, 'Privatization in Developing Countries: What are the Lessons of Recent Experience?' (2018) 33(1) The World Bank Research Observer 65. On the need for a legal system that facilitates privatisation, see M Breen and D Doyle, 'The Determinants of Privatization: a Comparative Analysis of Developing Countries' (2013) (15(1) Journal of Comparative 1, 8.

${ }^{30}$ World Bank, Sustainable Energy for All (World Bank Report 2017)

<https://data.worldbank.org/indicator/eg.elc.accs.zs > accessed 11 October 2019.
} 
electricity. ${ }^{31}$ Such minimal access has undermined development in Burundi as well as in Rwanda where the government has conceded that electricity access is critical to accelerating economic development. ${ }^{32}$ In Uganda, inefficient power system is partly due to relatively low generation capacity, poor transmission or distribution infrastructure and poor commercial utility practices. ${ }^{33}$ Although Kenya has the highest electricity access rate in East Africa, up to $25 \%$ of Kenyans still lack access to electricity. ${ }^{34}$ All these countries have responded to such challenges, in varying degrees, through a number of strategies. One such strategy is privatisation. In considering Partner States' individual approaches to liberalising the power market, it is necessary first to provide the legislative framework within such States have operated.

\subsubsection{Tanzania}

Tanzania developed the first National Energy Policy (NEP) in 1992 as a result of the socioeconomic reforms that took place during 1990s. ${ }^{35}$ Since then, there have been legislative reviews that culminated in the Electricity Act of 2008. This Act supported the increase in electricity supply, creation of a regulator-Energy and Water Utilities Regulatory Authority (EWURA), Rural Energy Agency (REA) and the Rural Energy Fund (REF). Despite this policy, there existed low private sector participation in the electricity supply, limited energy mix, expensive sources of energy supply and over-reliance on Government subsidies to develop power plants. The NEP of 2015 was then reviewed to address these issues. The demand for electricity has been growing at a rate of $10-15 \%$ per annum while the annual electricity consumption per capita is about $105 \mathrm{kWh}$. This is against the optimum global per capita consumption of $500 \mathrm{kWh} \cdot{ }^{36}$.

The NEP (policy) envisages the establishment of the legal and regulatory framework for an Independent System Operator (ISO), an Independent Market Operator. ${ }^{37}$ The policy also

\footnotetext{
31 ibid.

${ }^{32}$ World Bank, "Rwanda Economic Update: Making Electricity Accessible and Affordable"

<https://www.worldbank.org/en/news/feature/2019/07/01/rwanda-economic-update-making-electricityaccessible-and-affordable> accessed 11 October 2019.

${ }^{33} \mathrm{R}$ Tumwesigwe et al, 'Key Issues in Uganda's Energy Sector: Pro-Diversity Conservationists in Uganda (PROBICOU)' (International Institute for Energy and Development 2011).

${ }^{34}$ World Bank, "Kenya Charts Path to Achieving Universal Access to Electricity" <https://www.worldbank.org/en/news/feature/2018/12/06/kenya-charts-path-to-achieving-universal-access-toelectricity> accessed 11 October 2019.

${ }^{35}$ National Energy Policy (Ministry of Energy and Minerals 2015).

${ }^{36}$ MA Mondal et al., 'Ethiopian Energy Status and Demand Scenarios: Prospects to Improve Energy Efficiency and Mitigate GHG Emissions' (2018) Energy149, 161-172.

37 National Energy Policy (Ministry of Energy and Minerals 2015).
} 
emphasises targeted subsidies for strategic energy infrastructure investment. ${ }^{38}$ Although this policy may seem to benefit consumers, it is not conducive to competitive electricity markets. Electricity markets should be left to compete freely so that the price of electricity is costreflective and gives each participant equal ground in the supply bid. In 2016, the Tanzanian government developed the Electricity Act regulations (the Electricity Sector Re-Organisation Regulations) that are designed to promote competition and reorganising the electricity markets. ${ }^{39}$ These regulations provide guidelines on the market re-organisation such that all vertically integrated utilities, generation, transmission, and distribution are unbundled. ${ }^{40}$

Different stages of the unbundling are set up to run concurrently with the last component expected to be in place by June $2025 .^{41}$ Tanzania has established relevant legal and regulatory frameworks to attract private investment. ${ }^{42}$ With the enactment of these laws, Tanzania is clearly pursuing significant institutional changes in the energy sector. Several Independent Power Producers (IPPs), Emergency Power Producers (EPPs) and Small Power Producers (SPP) are participating in the electricity generation. ${ }^{43}$ However, there is still significant State control which is likely to continue in the short term. This is partly due to the practical challenge of 'low creditworthiness'. ${ }^{44}$ Furthermore, the strategic plan to phase out direct public ownership is not anchored to 'the necessary buy-in' and realisation of the plan is thus debatable. ${ }^{45}$ Tanzania will benefit from this research vis-à-vis the benefits of integrating the power markets in the region and the importance of expanding the market at the regional level. The differences in the individual capacities of Partner States can be illustrated through the Burundian experience.

\footnotetext{
38 ibid.

39 This was built on the Electricity Supply Industry Reform Strategy and Roadmap of 2014. See also the Electricity Act (CAP.131) regulations -Supplement No.42, The Electricity (Market Re-organisation and promotion of Competition) Regulation, 2016.

${ }^{40}$ ibid.

${ }^{41}$ ibid.

${ }^{42}$ The Electricity (Tariff Setting) Rules, 2016; the Electricity (Procurement of Power Projects and Approval of Power Purchase Agreements) Rules, 2017; the Electricity (Licensing Fees) Rules, 2016; the Electricity (System Operations) Rules, 2016; the Electricity (Market operations) Rules, 2016; the Electricity (Development of small Power Projects) Rules, 2016.

${ }^{43}$ OJ Mdee et al, “Assessment of Hydropower Sources in Tanzania” (2018) 3(4) Renewable Energy

Environmental Sustainability 1,9

${ }^{44}$ Mdee (n 45) 9.

45 A Eberhard, K Gratwick and L Kaiuki, 'A Review of Private Investment in Tanzania's Power Generation Sector' (2018) 29(2) Journal of Energy in Southern Africa 1,8
} 


\subsubsection{Burundi}

The Ministry of Water, Energy and Mining (MWEM) has the overall responsibility for the energy sector while the policies are implemented through the Directorate General of Water and Energy (DGEE) and the Directorate General of Hydraulics and Rural Electrification (DGHER). MWEM therefore supervises REGIDESO, which has a monopoly on electricity generation, distribution, and supply. Burundi suffers from inadequate transmission infrastructure and hence is faced with frequent load shedding resulting in many entities and homes resorting to personal generators.

In the EAC region, Burundi has the least installed capacity amounting to $34 \mathrm{MW}$ composed of hydropower and thermal power. The power sector is vertically integrated through Régie de Production et de Distribution d'Eau et d'Electricité (REGIDESO). The electrification rate and the peak demand is $2 \%$ and $100 \mathrm{MW}$ respectively, a capacity that is considered the lowest in the EAC region. ${ }^{46}$. The investment in the power sector stagnates while the demand continues to rise therefore causing a deficit and systematic load-shedding. The energy policy in Burundi focuses on three main areas: modernising existing power plants, reducing power demand, extending the power transmission infrastructure, and extending the electrification rate especially in rural areas. There are also plans to expand the transmission lines to tap renewables from solar power plants. ${ }^{47}$

Some key challenges inhibiting the expansion of the power sector include a lack of a proper legal framework that leads the IPP engagement, the limited human capacity and poor access to seed capital. Some specific laws enacted to attract IPP investment lack clarity on implementation. ${ }^{48}$ In particular, the lack of well-designed power tariffs discourages private investors from investing in the power sector. This means that electricity supply will continue to be a major issue unless there is significant improvement on the power tariff design and long term Power Purchase Agreements (PPAs) that support the investors who are interested in participating in the power generation sector. ${ }^{49}$ Law No. 01/14 of 2000 was enacted to liberalise and regulate the water and electricity sector. This law has been repealed by the new electricity law No 1/13 that was promulgated in 2015 to allow for public-private partnerships but still

\footnotetext{
${ }^{46}$ World Bank, 'Implementation completion and results report on a Global Environment Facility Grant -Energy Efficiency Project’ The World Bank 2016 (Report).

${ }^{47}$ Law No. 1/13 of 2015 for the re-organisation of the electricity sector in Burundi.

${ }^{48}$ E.g. Law No. $1 / 014$ of 2000.

49 AFDB, Burundi Country Strategy Paper 2012-2016 African Development Bank 2011 (Report).
} 
grants REGIDESO powers to remain as the main entity responsible for managing transmission and distribution networks. ${ }^{50}$

In 2011, a control and regulation entity was established by Decree No. 100/320 of 2011 to regulate and monitor activities related to water and electricity. ${ }^{51}$ This entity, Agency for the Water and Electricity sectors referred to as Authority for Regulation of Water and Energy Sectors (AREEN) is responsible for the regulation of electricity tariffs and proper application of pricing principles. About the same time, Decree No 100/318 of 2011 gave rise to the establishment of the Burundian Agency for Rural Electrification (ABER) which was meant to spearhead the expansion of the electrification rate to the rural population. Of great benefit to investors are Law No. 1/24 of 2008 and Law No. 1/23 of 2008 which directed the formulation of the new investment code outlining the tax benefits to investors. This therefore led to the establishment of the Investment Promotion Agency (IPA) in 2009 under Decree No. 1/177 of 2009 to improve the investment climate for foreign investors by serving as a one-stop shop for prospective investors in Burundi.

There is no exchange control in Burundi which implies that foreign investors are free to deposit their revenues outside Burundi. ${ }^{52}$ Law No 1/13 of 2015 is significant for power markets because it was promulgated to allow compliance with the Central Africa Power Pool (CAPP) procedures that declares an authorisation regime but does not allow for liberalisation in Burundi. The law transforms the Agency for the Water and Electricity sectors in Burundi into Agency Supervising and Regulating the Electricity Sector which is now a legal entity with financial autonomy. Although this law has the potential to align with the CAPP, it does not address the interconnection issues and therefore has not harmonised with the East African Power Pool (EAPP) regulations. These legal frameworks have promoted the development of several regional projects such as the new 200MW hydro-electric project and the ongoing transmission and distribution lines (86 km Ruzizi III-Bujumbura, 161km Rusumo fall line, and $143 \mathrm{~km}$ Kigoma-Gitega line). However, the 2015 Electricity Act does not allow for

\footnotetext{
50 The new electricity Law No.1/13 of 2015. However, this law is silent on the cross-border power trade and development of interconnectors -an inadequacy that potentially undermines regional harmonisation efforts.

${ }^{51}$ Regulation No.100/320 of 2011.

52 World Bank, Doing Business 2019: Training for Reform (World Bank Group 2019).
} 
liberalisation or the unbundling of the electricity sector. This is a key area that should be reviewed to facilitate power market coupling in the region. Such prerequisites can be compared with the legal and policy developments in Rwanda - a country that joined the EAC in the same era as Burundi.

\subsubsection{Rwanda}

In Rwanda, the Ministry of Infrastructure (MINIFRA), is responsible for the development of the relevant energy policies and for establishing necessary legal frameworks for the sector. The Rwanda Energy Group Ltd. (REG ltd) operates and maintains the power transmission system while the Rwanda Utilities Regulatory Authority (RURA) regulates the energy market through updating the grid code, enforcing the power service standards, reviewing the tariff structure, and licensing the power generation, transmission, and distribution companies. ${ }^{53}$ The main regulations guiding the electricity sector in Rwanda stem from the Investment Code (2014), PPP Law (2014), Electricity Act (2011), ${ }^{54}$ the Law Establishing and Determining the Mandate of the Rwanda Utilities Regulatory Authority and the Organic Law on Environment (2005).

The Electricity Act of 2008 was enacted to spearhead the unbundling of the then monopoly ELCTROGAS into Rwanda Energy Corporation (RECO) and Rwanda Water and Sewerage Corporation (RWASCO). The National Energy Policy and National Energy Strategy of 2011 and the Electricity Act of 2011 integrated RECO and RWASCO into a single entity called Energy and Water and Sanitation Authority (EWSA) a monopsony entity; also responsible for bulk transmission, distribution and retailing of power. Subsequently, the energy policy of 2011 was reviewed in March 2015. The 2015 energy policy addresses energy security, access, provision of robust legal framework, cost of generation and climate change, among other issues. ${ }^{55}$ The policy outlines, as one of its key objectives, the enhancement of regional cooperation and trade in electricity, including transmission network development. Although little is mentioned in the context of regional electricity trade, the various developments in the sector are geared towards achieving this goal.

\footnotetext{
53 The establishment of RURA in 2013 was provided in Law No 39/2001. This law further outlined the specifics of regulating the public utilities. However, this law was replaced with Law No 09/2013, reflecting a more extensive mandate for regulating the renewable and non-renewable energy technologies being developed and to contribute towards policy making as well as tariff regulation.

54 The Electricity Law No 21/2011 of 23/06/2011 governing electricity activities in Rwanda.

${ }^{55}$ Rwanda Energy Policy of 17 March 2015, developed by the Ministry of Infrastructure, Kigali.
} 
Like the case of Burundi, the review of relevant laws to open the market is critical to the development of a robust power market. This review could, in addition to ensuring promotion of electricity generation locally, provide guidance on cross border electricity trade. Overall, Rwanda is in the early stages of regional energy coupling with a view to giving the country a competitive edge under the regional power trade through a coupled electricity market. The development of appropriate legal frameworks and policies should be assessed in light of relatively minimal experience in power markets. This contrasts with the more extensive experiences of Uganda and Kenya - their experiences have evolved into significantly articulated positions. Thus, discussions will be relatively brief.

\subsubsection{Uganda}

The power sector in Uganda is hinged on three main policy documents: the Electricity Act of $1999,{ }^{56}$ the Energy Policy of 2002, ${ }^{57}$ and the renewable energy policy of $2007 .{ }^{58}$ The Electricity Act of 2007 ensured the unbundling and privatisation of Uganda Electricity Board (UEB) which was considered a monopoly. The main functions of the Electricity Regulation Agency include: to issue licenses for generation, transmission, distribution, supply and import from neighbouring countries. ${ }^{59}$ Among other powers, the Electricity Act of 1999 established the Electricity Regulatory Authority (ERA) and provided for the generation, transmission, distribution, sale and use of electricity to make the electricity sector competitive. ${ }^{60}$

Subsequently, Uganda Electricity Generation Company (UEGCL) was formed and is responsible for power generation. Competition has been introduced through the licensing of IPPs in power generation. This reform has expanded the electricity rate. The Ugandan energy policy addresses the security of electricity supply, access to affordable and modern source of energy, fostering sustainable economic growth and mitigating any environmental impacts related to energy supply.

\footnotetext{
56 The Electricity Act, 1999.

57 The Energy Policy for Uganda, 2002.

58 The Renewable Energy Policy, 2007.

${ }^{59}$ Cap 145. The main functions of ERA are stated in the Electricity Act of 1999, The Electricity Act of 1999 and the Public Enterprise Reform and Divestiture Act of 1993 formed the basis for the electricity reform in Uganda. ${ }^{60}$ Cap 145 s 61.
} 


\subsubsection{Kenya}

The electricity energy sector reform started with the unbundling of the then Kenya Power and Lighting Company (KPLC) into Kenya Electricity Generating Company (KenGen) in 1997, the formation of Rural Electrification Authority (REA) in 2007 and independent Energy Regulator in 2007. Kenya Electricity Transmission Company Limited (KETRACO) and the Geothermal Development Company Limited (GDC) were operationalised in 2008 as special purpose corporations to oversee the extension of the transmission network and speedy realisation of renewable energy respectively. The reform has led to the entry of several Independent Power Producers (IPPs) and the Kenya Nuclear Electricity Board (KNEB). ${ }^{61}$ The Kenya Electricity Generating Company and Kenya Power and Lighting Company have since undergone further partial privatisation.

The beginning of the accelerated reform process took shape at the adoption of the 2004 sessional paper No. 4 on energy. ${ }^{62}$ The paper highlighted two main objectives namely: to allow power generators to access bulk electricity consumer through the power transmission network and secondly, to create a domestic power pool that will allow the formation of a robust wholesale and retail market. The Energy Act of 2006 mandated the restructuring of the energy sector. ${ }^{63}$ Under this Act, various institutions have been formed thus permitting private participation and ownership of stakes in power generation. The new Energy Act of 2019 should give more impetus to the entry of private investors and outlines further institutional frameworks that are yet to be installed. ${ }^{64}$ This Act has further expanded the mandate of the regulatory agency-Energy Petroleum Regulatory Authority (EPRA) - formally known as Energy Regulatory Commission (ERC) and the added new roles for the Rural Electrification and Renewable energy (REREC)-Formerly known as REA, to include largescale power generation from RES. The formation of REREC will by far speed up the development of renewable energy and further expand the reform agenda in Kenya. Although the unbundling and corporatisation have progressed, the partly private entities continue to dominate. Consequently, the market concentration remains high even when more private investors have joined the market.

\footnotetext{
${ }^{61}$ ERC, Least Cost Power Development Plan (Energy Regulatory Commission 2012).

${ }^{62}$ Ministry of Energy, Sessional Paper No. 4 on Energy (Nyayo House, Nairobi 2004).

63 The Energy Act 2006 s 12(5)(d).

64 The Energy Act 2019
} 
In 2010, the Kenyan government promulgated a new constitution which among other issues led to the passing of other laws that are key to the development of energy in the national Government and the County Governments. The Transition to Devolved Government Act of 2012, ${ }^{65}$ the County Government Act, and the Urban Areas and Cities Act together are designed to shed light on legislative guidelines to the counties for providing devolved services including energy services. The renewable energy regulations were later drafted to guide in the development and installation of these resources. These include: The Energy (Solar Photovoltaic) Regulations, 2012, ${ }^{66}$ the Draft Energy (Improve Biomass Cook stoves, the Energy (Energy Management) Regulation, 2012 ${ }^{67}$ and the Energy (Solar Water Heating) Regulation, 2012. ${ }^{68}$ The Energy (Electricity Licensing) Regulation, 2012 sets out requirements for individuals carrying out generation, transmission, distribution, or supply of electrical energy in Kenya. ${ }^{69}$ Additionally, the Kenya Electricity Grid Code provides a consolidated standard of practices in the supply of electricity. This Code provides for scheduling and dispatch process, system security, and ring fencing and transmission and distribution network system. $^{70}$

\section{Fundamentals of Possible Convergence in the EAC}

\subsection{Common Denominators}

The EAC is driven by the need to foster customs union, common market, monetary union, and political federation. Energy market coupling is one of the pillars of the common market with an overarching objective of optimal supply, reliability, cost effectiveness, and environmentally friendly energy for the population. This objective extends to considering ways of attracting investment in the energy sector. As part of the agenda to secure reliable energy, the EAC in July 2017 adopted the Energy Security Policy Framework that outlines the measures to ensure energy security. ${ }^{71}$

\footnotetext{
65 The Transition to Devolved Government Act 2012.

66 The Energy (Solar Photovoltaic) Regulations 2012.

${ }^{67}$ Draft Energy (Improve Biomass Cook stoves, the Energy (Energy Management) Regulation 2012

${ }^{68}$ Energy (Solar Water Heating) Regulation 2012.

${ }^{69}$ This is complemented by the Energy (Complaints and Dispute Resolution) Regulation, 2012. Dispute resolution will be discussed in section 3 of this article.

${ }^{70}$ ERC, Kenya Electricity Grid Code (Energy Regulatory Commission 2008).

71 The Energy Security Policy Framework of the EAC (2017) urges the Partner States to: 1. develop national energy security policy, strategy and laws, 2. Establish institutional framework for energy security monitoring, 3. expand the mandate of the energy sector regulator to encompass downstream biomass energy, 4. engage development partners in supporting policy, strategy and institutional and human capacity development, 5. promote
} 
In pursuit of these objectives, the EAC market needs to take measures that support the sustainability and the security of supply of electricity within the market. One of the common foci identified in the comparative studies of the electricity laws in the countries under consideration is the drive to mitigate the environmental impact through promotion of investment in renewable energy across the region. The second common focus is the coupling of the electricity markets and promotion of liberalisation. These common ends can be achieved through consistent review and adoption of policy, laws and strengthening the institutions earmarked for supporting this transition.

The comparative study in the preceding section is further discussed to identify the level of convergence by highlighting the following: the foreseeable challenges to market coupling and barriers, the harmonisation of relevant electricity laws, determining the locus of convergence, and models that can support the power market structure.

\subsection{Impediments to Integration}

The EAC electricity markets are faced with threats to coupling which need to be addressed before the process of integration can start. First, the levels of the market structures vary considerably and they are at different levels of liberalisation. ${ }^{72}$ The power subsector in Burundi, Rwanda are predominantly vertically integrated, ${ }^{73}$ while Kenya, Tanzania and Uganda have unbundled the generation and the transmission. ${ }^{74}$ Secondly, while the five countries under examination have established national energy regulators, their independence has not been realised. ${ }^{75}$ The regulatory index as studied by the African Development Bank indicates that these Kenya, Uganda and Tanzania's index averages at about 0.75 while Burundi and Rwanda are below $0.5 .^{76}$ These indices therefore support the argument that the regulatory frameworks are at varying stages where, the former markets are at intermediate stage while the later, still at foundation stage.$^{77}$ Furthermore, these indices portray the impact of attracting investment in

\footnotetext{
regional cooperation for energy security management based on common challenges, and 6. develop and strengthen national capacity in energy sector statistics and an energy security monitoring database.

${ }^{72}$ EAC, East African Community Vision 2050: Regional Vision for Socio-Economic Transformation and Development (EAC 2015).

73 EAPP Regional Power Master Plan (Eastern Africa Power Pool 2014).

74 ibid.

75 This is especially so as State regulators will remain relevant for the foreseeable future especially with respect to the transmission lines and overall consumer protection.

${ }^{76}$ Electricity Regulatory Index for Africa (Africa Development Bank 2018).

77 ibid.
} 
infrastructure in the region that is key to establishing the coupling of the market, as well as highlighting foreseeable risks such as institutional stability and macroeconomic risks. Thirdly, the lack of strong infrastructure in the internal markets as well as cross border lines hinder the development of an internal energy market for the region. Some development partners and institutions are working towards ensuring expansion of high voltage transmission line which are vital in enhancing electricity trade amongst the countries. ${ }^{78}$ However, the harmonisation of the energy policies should be spearheaded to provide robust market rules that ensure operationalisation of the market is smooth. Fourthly, a close look at the weak transmission infrastructure reveals that the EAC has not yet established robust cybersecurity critical for the energy infrastructure. ${ }^{79}$ Cyber-resilient energy systems are critical to an integrated market such as that advocated for the EAC where there is an expectation of highly interconnected systems.

The challenges in the current market structure that can delay the coupling concern the differences in levels of electricity market liberalisation and the willingness of the individual countries to initiate necessary laws and regulations to enforce market coupling. Kenya, Tanzania, and Uganda have already made significant steps towards liberalisation through partial unbundling of their power sectors. They have also drafted some laws that foresee regional power trade with the neighbouring countries. Burundi is yet to develop laws that allow restructuring in the power sector and that sector remains vertically integrated. The EAC has, however, taken several initiatives to support the region in enacting robust laws that will support regional power trade. As will be further discussed in detail shortly, the region will move more quickly towards harmonisation of the electricity laws if Burundi and Rwanda can expedite the review of their laws to allow further restructure and competition laws. ${ }^{80}$ Furthermore, the establishment of a regional institution that focuses on the harmonised approach to relevant Partner States' laws would facilitate restructuring faster as opposed to individual countries working independently. It would help to have more laws with certain principles of coupling spelling out the regulatory environment and the boundaries of legitimacy from which other local electricity laws could stem. Such a regional body will also be subject to, and benefit from, the harmonisation efforts of the East African Court of Justice (EACJ) to be discussed shortly. It is necessary to contextualise the efforts of legal harmonisation considering dispute resolution in the region and the pivotal role of the EACJ.

\footnotetext{
78 ibid.

79 This will be discussed in section 5 of this article.

${ }^{80}$ This is without prejudice to the EAC principle of variable geometry that will be discussed in the next section of this article.
} 


\subsection{Dispute Resolution and Investor Confidence}

Disputes are inevitable in the course of dealing with projects that often involve international elements. This is especially so as supplies and expertise may be required from abroad. It is somewhat ironic that the justice system itself is sometimes undermined by epileptic power supply and the need for expensive back-up generators. ${ }^{81}$ Furthermore, there are several challenges of the justice systems that are common in the East African community. Examples include expensive litigation processes, ${ }^{82}$ inadequate or no published reports of commercial cases decided by appellate courts, ${ }^{83}$ and corruption in the judiciary. ${ }^{84}$ Individual Partner States have made certain individual efforts in addressing some relevant legal and justice system challenges. ${ }^{85}$ However, relevant legal reform should be built on a dispute resolution synergy in the EAC to prevent any weak link from undermining overall progress in the electricity sector. It is, therefore, necessary to provide an analytical overview of Partner States.

Agreements form a core element of international commercial transactions concerning electricity supply. ${ }^{86}$ In this context, the need for efficient dispute resolution is necessary especially in developing countries vis-à-vis regional frameworks. ${ }^{87}$ There have been clear judicial efforts to ensure agreements are protected and respected. This should build investor confidence which is critical to sustainable progress in this area of power markets coupling. An example is Dowans Holding SA $v$ Tanzania Electric Co Ltd. ${ }^{88}$ Both parties executed an emergency power off-take agreement until Tanzania Electric Co Ltd (the defendant) argued

\footnotetext{
${ }^{81}$ For this point in Uganda, see Legal Assistance for Economic Reform, 'Retrospective Study of the Progress, Performance and Impact of the Uganda Commercial Court 1996-2015' (Report of 6 November 2015) para 5.5. <https://assets.publishing.service.gov.uk/media/591b07e6e5274a5e4e000010/uganda-com-ct-study.pdf> accessed 5 October 2019.

82 J Mawejje, E Munyambonera, L Bategeka, 'Uganda's Electricity Sector Reforms and Institutional Structuring' - Research Series No 89 (Economic Policy Research Centre, 2012) 25.

${ }^{83}$ For an insight into Burundi, see World Bank, 'Doing Business 2019: Economic Profile Burundi' (A World Bank Group Flagship Report) 45.

<http://documents.worldbank.org/curated/en/240471541067681956/pdf/131613-WP-DB2019-PUBLICBurundi.pdf $>$ accessed 5 October 2019

${ }^{84}$ Burundi enacted specific legislation to tackle corruption in the judiciary. See Law No 1/36 of 13/12 2006 that established the anti-corruption court within the judiciary. See also, African Development Bank Group

: Republic of Burundi Country Strategy Paper 2019-2023 (African Development Bank 2019) XXVI $<$ https://www.afdb.org/sites/default/files/documents/projects-andoperations/burundi_country_strategy_paper_2019-2023-rev.pdf> accessed 11 October 2019.

${ }^{85}$ S Bimenyimana, GNO Asemota, and L Li, 'The State of the Power Sector in Rwanda: A Progressive Sector with Ambitious Targets' (2018) Frontiers in Energy Research: Policy and Practice Review 1, 2.

${ }^{86} \mathrm{~T}$ Ziesemer, 'Renewable Energy Supply, Infrastructure and Gains from International Trade in Electric Current' (2019) 17 Applied Economics Letters 1439, 1442.

${ }^{87}$ In the context of African integrated power markets, see MO Oseni and M Pollitt, 'Institutional Arrangements for the Promotion of Regional Integration of Electricity Markets: International Experience' EPRG Working Paper 1408 Cambridge Working Paper in Economics 1458 (Energy Policy Research Group 2014) 6-9.

88 [2011] EWHC 1957 (Comm).
} 
that the agreement was void from the beginning since it contravened the Tanzanian Public Procurement Act of 2004. An International Chamber of Commerce tribunal decided that the agreement was valid, so the tribunal ordered payment and awarded damages. The defendant petitioned the Tanzanian High Court where the award had been filed for it to be set aside or remitted for reconsideration. The English court granted permission to D to enforce the award in England. Although the English court considered that the defendant's arguments were not fanciful in light of Tanzanian case law, ${ }^{89}$ it safeguarded the claimant's position 'in relation to their loss of opportunity' by ordering security in the sum of $\$ 5 \mathrm{~m}$ as a condition for granting an adjournment. ${ }^{90}$ It is also instructive that Tanzanian and Kenyan authorities were considered in trying to delimit the scope of public policy. ${ }^{91}$

In a recent judgment, the Kenyan Court of Appeal approved the decision in the Tanzanian case of $D B$ Shapriya \& Co Ltd $v$ Bish International $B V$ and gave a narrow interpretation of 'misconduct' to ensure the arbitrator's findings of fact were not undermined. ${ }^{92}$ The court decided that judicial intervention should be limited to errors of law which are apparent on the face of the record. ${ }^{93}$ The court denied the application to set aside the award and observed that the expedition, efficacy and finality were supposed to make arbitration a better option to litigation. ${ }^{94}$ Although arbitration is ideal in principle, especially in the context of trying to attain a fair resolution of disputes, it may pose its own challenges in the power sector. It is important to assess any contextual challenges as countries such as Tanzania move towards increased privatisation in the generation of electricity. ${ }^{95}$ For example, a balance should be struck between promoting privatisation and ensuring its benefits are not undermined through expensive or lengthy dispute resolution processes.

In Uganda, there are efforts to ensure the dispute resolution process succeeds in the electricity sector. For example, Jinja Produce \& Millers Association Ltd v Umeme (U) Ltd signed contracts for the supply of electricity to the grinding mills of several applicants. ${ }^{96}$ A single arbitrator was appointed through intervention powers after the applicants repeatedly failed to

\footnotetext{
${ }^{89}$ Para 44. See the Tanzanian case of DB Shapriya \& Co Ltd v Bish International BV (No 2) [2003] 2 East Africa Law Report 404 (HCT).

90 (n 88) para 53.

${ }^{91}$ Para 11(e). See also the Kenyan case of Christ for All Nations v Apollo Insurance Co Ltd [2002] 2 East Africa Law Report 366, 370 (CCK).

${ }^{92}$ See the Kenyan case of Nairobi Golf Hotels Ltd v Linotic Floor Co Ltd [2015] eKLR.

${ }^{93}$ ibid.

94 ibid.

${ }^{95} \mathrm{~K}$ Gratwick, R Ghanadan and A Eberhard, 'Generating Power and Controversy: Understanding Tanzania's Independent Power Projects’ (2006) 17(4) Journal of Energy in Southern Africa 39, 52.

96 [2017] UGCADER 2.
} 
agree on how a three-man arbitrator panel would be constituted. ${ }^{97}$ Uganda has a tribunal dedicated to electricity matters and it has jurisdiction to determine any matter concerning the electricity sector. ${ }^{98}$ The Ugandan courts have also held State agencies accountable in cases where damages have been awarded, ${ }^{99}$ decided claims were not time barred against investors, ${ }^{100}$ and refused to indulge litigants who try to delay court proceedings. ${ }^{101}$

Rwanda and Burundi belong to a legal tradition different to Tanzania, Kenya and Uganda. While the latter were former British colonies and thus influenced by the English common law, the former have a different colonial history and thus influenced by civil law. ${ }^{102}$ The central importance of binding precedent, a distinctive feature of the English common law, arguably helped to develop the jurisprudence of Tanzania, Kenya and Uganda. ${ }^{103}$ Nevertheless, Rwanda has demonstrated great resolve to overhaul its dispute resolution system. For example, one of Rwanda's legal reforms was introducing the doctrine of binding precedent into the Supreme Court. ${ }^{104}$ This has been supported with a clear alignment with the EACJ and Rwanda has benefited from this alignment. In Union Trade Centre Limited (UTC) $v$ the Attorney General of Rwanda ${ }^{105}$ for example, the Appeal Division of the EACJ decided that it was wrong for the trial court to adjudicate the case instituted by the applicant without evidence in a situation where factual evidence was clearly called for.' ${ }^{106}$ The trial court was asked to hear the matter afresh.

Burundi has more challenges with respect to the dispute resolution system generally. Burundi has continuously ranked lowest in the East Africa Bribery Index for more than half a decade. ${ }^{107}$ The judiciary is one of the institutions most affected by petty corruption. ${ }^{108}$ Burundi has tested the interpretative ingenuity of the EACJ and a good illustration is Desire v the Attorney General

\footnotetext{
${ }^{97}$ Ibid. see s 11(3)(b) of the Arbitration and Conciliation Act of 2000.

${ }^{98}$ Electricity Disputes Tribunal (Procedure) Rules 2012 rule 4.

${ }^{99}$ Kikoni v Uganda Electricity Board [2005] UCHC 106.

${ }^{100}$ Abhul Bait (A.S) Islamic Foundation Uganda Ltd (ABIFU) v Uganda Electricity Distribution Company Ltd (UEDCL) [2015] UGCOMMC 109.

${ }^{101}$ Uganda Electricity \& Allied Workers Union v Umeme (U) Ltd [2018] UGIC 22.

102 German and Belgian civil law systems. The EAC considered that the differences in both legal systems was a significant hinderance to the unification <https://www.newtimes.co.rw/section/read/8742> accessed 7 May 2019.

${ }^{103}$ On the doctrine of binding precedent (stare decisis), see SR Perry, 'Judicial Obligation, Precedent and the Common Law' (1987) 7(2) Oxford Journal of Legal Studies 215.

${ }^{104}$ Art 47 of No 03/2012/OL of 13/06/2012 Organic Law Determining the Organisation, Functioning and Jurisdiction of the Supreme Court https://nppa.gov.rw/fileadmin/Archive/LAWS_FILES/UBUBASHA_BWA_SUPREME_COURT.pdf

${ }^{105}$ Appeal No 1 of 2005 - an appeal from the judgment of the First Instance Division.

${ }^{106}$ ibid para 43.

107 https://www.bti-project.org/en/reports/country-reports/detail/itc/BDI/

108 ibid.
} 
of Burundi. ${ }^{109}$ The applicant, a Burundian, argued that his property rights were violated. Essentially, the applicant was not satisfied with the decision of the Burundian Supreme Court. The applicant argued that Burundian law was misapplied, reasons not given for its decision and failing to provide adequate guidance on the legal and probative value of attested affidavits thus creating legal uncertainty. ${ }^{110}$ The EACJ observed that it was necessary to provide 'coherent legal justification for the conclusions arrived at' despite the civilian legal tradition background of Burundi. ${ }^{111}$ Although a 'cavalier judicial approach was depicted in the impugned judgment', there was insufficient evidence that the rule of law was contravened vis-à-vis the Treaty. ${ }^{112}$ It should be emphasised that these arguments are not predicated on any supranational enforcement mechanism. ${ }^{113}$ The point is that the EACJ can shape regional integration through a progressive and contextual application of the EAC Treaty. ${ }^{114}$ Developing a coherent jurisprudence with respect to EAC Treaty provisions requires a consideration of domestic laws to ensure legal convergence is not undermined. In this regard, it would be challenging to ensure a harmonised approach to dealing with legal and industry impediments to power coupling if relevant institutions are absent or inefficient.

\subsection{Institutions for Convergence}

As already stated, individual Partner States have made certain efforts in domestic legal reform. In Kenya, for example, the electricity sector Energy Tribunal was formed in 2007 as an independent committee to arbitrate any disputes between the regulator and the investors. ${ }^{115}$ Regardless of how well domestic courts may be willing to determine relevant matters that are brought before them, there is usually a possibility that a clear alignment of domestic interests and Community interests may be a challenge. Striking a balance between the interests of Partner State governments, the EAC and private litigants requires a clear understanding of how communal interests should be advanced without undermining the individual Partner States' fundamental laws and public policies. Accepting judicial interpretation at the regional level is

\footnotetext{
${ }^{109}$ Reference No 8 of 2015.

110 ibid para 37.

111 ibid para 41.

112 ibid para 80.

113 JE Ruhangisa, 'The Scope, Nature and Effect of EAC Law' in E Ugirashebuja et al, East African Community Law: Institutional, Substantive and Comparative EU Aspects (Brill 2017) 139, 153. For the challenges of supranationalism in the EAC, see B Fagbayibo, 'Common Problems Affecting Supranational Attempts in Africa: An Analytical Overview’ (2013) 16(1) Potchefstroom Electronic Law Journal 32, 39-43. See also KJ Alter, JT Gathii and LR Helfer, 'Backlash against International Courts in West, East and Southern Africa: Causes and Consequences’ (2016) 27(2) European Journal of International Law 293, 300.

114 ibid 139.

${ }^{115}$ S 108 of the Energy Act 2006 Cap 314 [Rev. 2012].
} 
not new to the East African region. For example, the erstwhile East Africa Court of Appeal sometimes endorsed decisions of the English House of Lords. ${ }^{116}$ Such decisions have remained useful in contemporary times in some cases where electricity stakeholders are litigants. ${ }^{117}$ The East African Court of Justice has made considerable efforts to navigate the area of intersections between Partner States' municipal laws and the EAC Treaty.

In Kyarimpa $v$ the Attorney General of Uganda, ${ }^{118}$ a case concerning the construction of the 600 MW Karuma Hydroelectric Plant, one of the issues was whether the trial court was wrong to decide that the 'selection and subsequent signing of the MoU between the GoU and Sinohydro' was consistent with articles 6,7 and 8 of the Treaty. ${ }^{119}$ This was on the basis that Ugandan public procurement law and Ugandan court orders had been violated. ${ }^{120}$ The relevant Treaty provisions generally concerned good governance and accountability, ${ }^{121}$ as well as abstaining from measures 'likely to jeopardize the achievement of those objectives or the implementation of the provisions of the Treaty'. ${ }^{122}$ The Appellate Division of the East African Court of Justice accepted the appellant's submission that since the trial court found that no 'written bilateral agreement' was produced before the court, it was wrong to infer that such an agreement existed merely based on inferences drawn from other documents including correspondence between government officials in Uganda. ${ }^{123}$ It is instructive that apart from the Ugandan Constitution which referred to the 'execution' of agreements, Ugandan public procurement law contained mandatory provisions. ${ }^{124}$ Although the Appellate Division did not specifically mention the issue of public policy, it is clear that considering the implications for Ugandan mandatory law and constitutional provisions was important. Ironically, the Ugandan government was in breach of Ugandan procurement laws and such conduct was likely to jeopardise the aims of the Treaty. ${ }^{125}$ This case also illustrates the point that while public policy would be interpreted narrowly to ensure that investor confidence is not jeopardised, there

\footnotetext{
${ }^{116}$ In the context of assessing evidence at the trial court, see Peters $v$ Sunday Post Ltd [1958] 1EA 424 where the East Africa Court of Appeal approved the decision of the House of Lords in Watt v Thomas [1947] AC 484. See also Uganda Electricity Distribution Company Ltd v Commissioner General Uganda Revenue Authority [2013] UGCOMMC 2.

117 Uganda Electricity Distribution Company Ltd v Commissioner General Uganda Revenue Authority (n 116). 118 Appeal No 6 of 2014 - an appeal from the judgment of the First Instance Division.

${ }^{119}$ Specifically, art 6(c) and (d), 7(d), and 8(1). See para 63 of the judgment.

${ }^{120}$ S 4(1) of the Public Procurement and Disposal of Assets Act 2003 and s 5(1) of the Public Procurement and Disposal of Public Assets Regulations 2003.

${ }^{121}$ Art 6(d) and 7(2).

${ }^{122}$ Art 8.

${ }^{123}$ Para 70 of the judgment.

${ }^{124}$ S 4(1) of the Public Procurement and Disposal of Assets Act 2003.

${ }^{125}$ Para 72 of the judgment.
} 
should be enough room to strike a balance between individual litigant or State interests and a harmonised approach to matters concerning the power sector.

Kyarimpa $v$ the Attorney General of Uganda seemed to be an elaboration of a trajectory that had been charted by the EACJ to ensure a proper navigation of the intersections between individual partner States laws and the EAC Treaty. In the context of Rwanda, the EACJ had earlier observed that a violation of individual State laws and procedures amounted to a violation of the rule of law and, by extension, contravened the Treaty. ${ }^{126}$

The courts can promote harmonisation through encouraging a strategic implementation of domestic laws and a progressive interpretation of the Treaty. A cooperative approach towards harnessing energy is critical to reducing inefficiency. The otherwise varied and complicated nature of domestic laws would impede uncertainty for foreign investors. There is evidence that harmonisation of energy laws in trade communities results in increased efficiency and approvals for the energy sector thereby cutting one or two years off the overall approval process (thereby allowing project development to occur faster) and enhancing domestic GDP by upwards of $8 \%-10 \% \cdot{ }^{127}$ A progressive navigation of the intersections between domestic and Treaty provisions will create the jurisprudential impetus to inspire Partner States that experience more challenges to strive towards genuine improvement. In this manner, investor confidence will be buoyed by the safety net and support of the Community. This approach will also ensure a practical application of the variable geometry provided under the Treaty. This practical application will also support the establishment of a regional body earlier discussed. ${ }^{128}$ The establishment of a regional body will assist in the process of liberalisation and restructuring through provision of capacity building and other relevant formulations that are necessary to promote smooth transition from the current structure to an integrated energy market for the regions. This entity will also define the locus of convergence. This convergence will help to ensure energy security, reduce greenhouse emissions, promote competition and investment, and develop shared infrastructure for the region. The recognition and structuring of an appropriate locus of convergence is critical to the subsequent coupling process because such convergence will promote foreign investment. There are two identifiable loci of energy convergence. These are energy security and lowering of greenhouse gas emission. The laws

\footnotetext{
${ }^{126}$ Rugumba v Attorney General of Rwanda EACJ Ref No 8 of 2010. See also Muhochi v the Attorney General of Uganda EACJ Ref No 5 of 2011.

${ }^{127}$ A Tharani, 'Harmonization in the EAC' in E Ugirashebujah, East African Community Law: Institutional, Comparative and Substantive Aspects (Brill 2017) 486, 487.

${ }^{128}$ In the preceding section of this article.
} 
of Kenya and Tanzania stipulate strategies to promote competition in the electricity market. Generally, there is vast literature on promoting the energy security component as a precursor to economic growth. ${ }^{129}$

On the component of models for supporting the power structure, much has been discussed and some models of the design of the electricity market developed. A good electricity market design for the EAC can adopt an appropriate Renewable Energy Continuum (RIC) model from amongst other structures to smoothly gravitate the transition. Laws and policies are spearheaded by various entities entrusted with the development and enactment. However, political will is a vital element in ensuring that the whole process is feasible. Such willingness is an important context within which regional institutional integration and electricity market coupling should thrive.

\section{Regional Institutional Integration and Electricity Market Coupling}

The EAC is considered as one of the most integrated markets in Africa. Substantial initiatives to integrate these markets have emerged since these Partner States ratified the EAC Common Market Protocol (CMP) on the establishment of a common market and came into force in $2010 .{ }^{130}$ The integration process that began in 2005 on the inauguration of the EAC Customs Union to enhance the removal of barriers to trade. There are several options for electricity market coupling, and these will be discussed.

In considering regional institutional integration, it is difficult to isolate such institutions from the political contexts in which such institutions are situated. ${ }^{131}$ Regional integration, which involves intersections between laws and political economies, allows the willing parties or countries to cooperate on some agreed objectives. ${ }^{132}$ Notable objectives include economic cooperation, political federation or security cooperation and removal of trade barriers as well as allowing for free movement of people within the region. For example, the planned pooling of electricity for nine countries was thwarted due to the politics involving the use of the River

\footnotetext{
${ }^{129}$ See generally: MJ Pasqualetti and BK Sovacool, 'The Importance of Scale to Energy Security' (2012) 9(3) Journal of Integrative Environmental Sciences 167. See also DA Deese, 'Energy, Economics, Politics and Security' (1980) 4(3) International Security 140.

130 The Protocol on the Establishment of the East African Community Common Market of 2009.

${ }^{131}$ See generally, D Peng and R Poudineh, 'Electricity Market Design for a Decarbonised Future: An Integrated Approach' (The Oxford Institute for Energy Studies 2017). See also, CB Jensen and JB Slapin, 'Institutional Hokey-Pokey: the Politics of Multispeed Integration in the European Union' (2012) 19(6) Journal of European Public Policy 779.

${ }^{132}$ MA Wilkinson and H Lokdam, 'Law and Political Economy' LSE Law, Society and Economy Working Papers 7/2008 1, 10 .
} 
Nile thus leading to countries opting out of the gentleman's agreement to pool the electricity markets. ${ }^{133}$ For a robust electricity market to exist, proper political risk analysis for the EAC countries through appropriate instruments to assess the willingness of the parties to enter into long term relationships for engaging the power markets competitively is vital. The political stability of the Partner States under consideration is key to the smooth transition to the power markets and various plans are in process of being instituted.

The political stability in these countries is addressed in the political integration pillar as proposed in the Northern Corridor Integration projects (NCIP). ${ }^{134}$. The political federation component agreed upon includes, a development of a framework for the political federation for the countries, and development of a constitution to guide in the political integration of the countries. This followed the first agreement in the initial summit of the heads of states in 2013. ${ }^{135}$ The political federation component is currently spearheaded by the EAC secretariat. ${ }^{136}$ The EAC is rapidly growing economically but the recurrent interruptions resulting from political instability dictate the future of the willingness of these countries to work together for economic growth in the region. ${ }^{137}$ However, the coalition of the willing states towards political integration under the NCIP is a positive sign that the cooperation of these countries is foreseeable. Some of the key initiatives under the political integration are shaped by the international development agencies who to a large extent contribute towards the infrastructural development and consequently the economic growth.

To promote regional institutional integration, it is imperative that proper institutions address conflict avoidance and promote political integration are supported. It is necessary to create robust institutional support and having regular meetings to discuss the strategies that can be carried out to ensure that the region benefits from regional peaceful co-existence and to foster development in the region. These should be followed by capacity building of the institutions to carry out monitoring of the impact of the non-political cooperation on economic growth in the region.

\footnotetext{
${ }^{133}$ A Swain 'Challenges for Water Sharing in the Nile Basin: Changing Geo-Politics and Changing Climate' (2011) 56(4) Hydrological Science Journal 687-702.

${ }^{134}$ The $6^{\text {th }}$ Northern Corridor Integration Project, Ministerial Report of 2 July 2014.

135 See the 1st Northern Corridor Integration Project Summit, 2013 <http://www.works.go.ug/2015/06/07/10thnorthern-corridor-integration-projects-summit-kampala-press-release-thursday-28th-may-2015/> accessed 5 October 2019.

136 ibid.

${ }^{137}$ In this regard, South Sudan is particularly illustrative.
} 
Political integration should not be isolated from other aspects of regional cooperation such as the facilitation of international commerce and the promotion of security. Hitherto, various initiatives have been developed to spearhead the security and cooperation in the region starting from the African Union (AU) level to the country level. Amongst the achievements attained to date on regional integration are the various initiatives under the political federation which notably include: the adoption of the AU Agenda 2063, the updated EAC regional Strategy on Peace and Security that was adopted in 2014 by the Council of Ministers that aimed at addressing crime management, and conflict resolution amongst the member states. ${ }^{138}$ These two broad categories have been initiated through other programmes such as the 'Silencing the Guns 2020' that considers promoting trade and free movement of people in the block. In tandem with such programmes, there is a deliberate effort by the heads of states to form some Panel of Eminent persons to oversee and foster what is called preventive diplomacy. ${ }^{139}$

There is room for more sustainable progress in the $\mathrm{EAC}$ with respect to regional power markets integration. This concerns two major areas that have legal implications. The first is a contextual and practical understanding of security. The second concerns the assessment of regional strategy. Generally, sub-Saharan African countries have not expanded the contextual meaning of security to include cyber matters. As at 2016, more than half of the 54 African countries lacked specific legislation to combat cybercrime. ${ }^{140}$ This trend does not reflect the urgent need to factor in cybersecurity in the African electricity market, especially in sub-Saharan Africa. Efficient power markets are inextricably connected with technological advancements such as the digitalisation of the energy sector generally. ${ }^{141}$ The need for a deliberate and thoughtful approach to cybersecurity can be illustrated through the recent experience of South Africa. Although South Africa has sustained pioneering efforts to modernise its electricity sector for many years, ${ }^{142}$ a major South African power company suffered a ransomware attack in Johannesburg. The virus encrypted all databases, applications and network. ${ }^{143}$ The East Africa Community should leverage African regional efforts to harmonise efforts aimed at combatting

\footnotetext{
${ }^{138}$ AU, Agenda 2060: The Africa We Want (African Union 2014).

139 ibid.

${ }^{140}$ N Kshetri, 'Cybercrime and Cybersecurity in Africa' (2019) 22(2) Journal of Global Information Technology Management 77, 78.

${ }^{141}$ See the Cyber Security in the Energy Sector: Recommendations for the European Commission on a European Strategic Framework and Potential Future Legislative Acts for the Energy Sector (EECSP Report 2017) 16 <https://ec.europa.eu/energy/sites/ener/files/documents/eecsp_report_final.pdf> accessed 5 October 2019.

142 J Liu et al, 'Cyber Security and Privacy Issues in Smart Grids' (2012) 14(4) IEEE Communications Surveys \& Tutorials 981.

${ }^{143}$ 'Ransomware hits Johannesburg's electricity supply' < https://www.bbc.co.uk/news/technology-49125853 > accessed 5 October 2019.
} 
cybercrime, and it is necessary to consider the electricity market in a specific manner. The most recent Kenyan legislation on cybercrimes has the potential to inspire neighbouring countries to prioritise international cooperation. ${ }^{144}$ This is because the Act contains several provisions in this regard. ${ }^{145}$ The provisions on mutual assistance consolidate previous efforts on mutual legal assistance generally. ${ }^{146}$

A plan to establish the Eastern Africa Power Pool (EAPP) has been consolidated since the commencement of the Treaty for the establishment of the East Africa Community. ${ }^{147}$ This resulted in signing of an Inter-Governmental Memorandum of Understanding (IGMOU) for the establishment of the Eastern Africa Power Pool (EAPP) in 2005 and subsequently establishment of the regional strategy on scaling up access to modern energy services in the EAC. The progress has, however, been impeded by the focus of national strategies to increase energy access and reduction of poverty. The approach taken by the governments should be more holistic and proactive. For example, opening the electricity market for the region would not only yield higher economic welfare but also attract potential investment in the energy sector. Approaching the transmission investment planning at a regional level and establishing institutions that will ensure the harmonisation of the laws in the region will support the speedy development of an integrated electricity market.

\section{Conclusion}

This article has explored relevant practical areas and legal frameworks applicable to the Partner States of the East African Community. This has been done with a view to articulating how policy and legal harmonisation can be achieved in the regional market. The search for a common core has been conducted through a comparative analysis of similarities and differences by considering some themes. These include: key legislation that support the development of renewable energy, objectives of relevant electricity laws, structure of the regulatory support mechanisms, structure of the electricity sector and impediments to future electricity sector expansion.

Countries such as Kenya, Tanzania and Uganda have made significant steps towards liberalisation through partial unbundling of their power sectors. These countries have also

\footnotetext{
144 The Computer Misuse and Cybercrimes Act 2018.

145 See ss $57-65$ of the Act.

146 Mutual Legal Assistance Act 2011.

147 The Treaty for East African Co-operation Act 1967.
} 
enacted some laws that support regional power trade with the neighbouring countries. ${ }^{148}$ However, Burundi is yet to develop laws that allow restructuring in the power sector and the sector remain vertically integrated. Rwanda has bridged the gap between Kenya, Tanzania and Uganda on the one hand, and Burundi on the other. Despite its historical civil law background, Rwanda has consolidated legal reform that has promoted legal certainty necessary for investor confidence. ${ }^{149}$ The need to promote and protect foreign investment in the region underscores the importance of a harmonised approach to the electricity market.

In assessing the convergence of existing laws, which are useful in supporting anticipated electricity market coupling, there are substantial elements of the electricity laws in the various countries that need to be developed which especially promote regional power trade and increased competition. Furthermore, the establishment of a regional regulator to oversee the implementation of the future power market coupling and promoting liberalisation in the region is critical. This entity could focus on harmonisation of the laws among the Partner States of the EAC: develop market rules and regulation; monitor the power market, and capacity building for local institutions. In this context, the East African Court of Justice can play a pivotal role to ensure robust jurisprudence and adequate institutional support. As several judgments of the Court have illustrated, ${ }^{150}$ it is necessary to have a clear idea of how communal objectives should be prioritised in a pragmatic manner that does not undermine trust among the EAC Partner States and institutions. ${ }^{151}$ In this way, sustainable progress towards the ambitious targets of the EAC would be attainable.

\footnotetext{
${ }^{148}$ As earlier argued, the legal systems/traditions of this country seem to have expedited the development of their jurisprudence. See text to $\mathrm{n} 103$.

${ }^{149}$ See generally section 4.3 of this article.

${ }^{150}$ E.g. Kyarimpa $v$ the Attorney General of Uganda (n 118).

${ }^{151}$ On the importance of appearances vis-à-vis trust and regional integration, see GM Genna, 'Positive Country Images, Trust and Public Support for European Integration’ (2008) Comparative European Politics 1.
} 